\title{
Filsafat Kewarisan dalam Hukum Islam
}

\author{
Nur Lailatul Musyafaah \\ VISN Sunan Ampel Surabaya | nurlailashafaa@gmail.com
}

\begin{abstract}
One of the important events experienced by man is death, that is the final process of human life. Because it is a legal event, the death has legal consequences, namely the law of inheritance, is the event of the transfer of property left by the dead to the heirs. In Islamic law, inheritance law is a law that regulates all things concerning the transfer of rights and / or obligations on one's property after he dies to his heirs. In Islamic law there are six principles, are (1) the principle of ijbary, (2) the principle of waratha, (3) the principle of thuluthay al-mal, (4) bilateral principle, (5) the principle of equity or equilibrium, 6) individual principles. While in the Islamic heritage in Indonesia there are three principles adopted, as in the Compilation of Islamic Law (Kompilasi Hukum Islam/KHI), are: (1) the principle of ijbary, (2) the principle of waratsa, and (3) bilateral principle.
\end{abstract}

\begin{abstract}
Abstrak: Salah satu peristiwa penting yang dialami oleh manusia adalah kematian, yaitu proses akhir dari kehidupan manusia. Karena merupakan peristiwa hokum, kematian tersebut malahirkan akibat hokum, yaitu hukum waris, yaitu beralihnya harta yang ditinggalkan orang yang mati kepada ahli waris. Dalam hokum Islam, hukum kewarisan adalah hukum yang mengatur segala sesuatu yang berkenaan dengan peralihan hak dan atau kewajiban atas harta kekayaan seseorang setelah ia meninggal dunia kepada ahli warisnya. Dalam hokum waris Islam terdapat enam asas, yaitu (1) asas ijbarry, (2) asas waratha, (3) asas thuluthay al-mal, (4) asas bilateral, (5) asas keadilan atau keseimbangan, dan (6) asas individual. Sedangkan dalam pewarisan Islam di Indonesia terdapat tiga asas yang dianut, sebagaimana dalam Kompilasi Hukum Islam, yaitu: (1) asas ijbary, (2) asas waratsa, dan (3) asas bilateral.
\end{abstract}

Kata kunci: hokum kewarisan, asas-asas hokum kewarisan Islam

\section{A. Pendahuluan}

Dalam kehidupan setiap manusia, pada umumnya mengalami tiga peristiwa penting, yaitu: kelahiran, 
perkawinan dan kematian (meninggal dunia). ${ }^{1}$ Kematian merupakan proses akhir dari hidup manusia. Bagi manusia sebagai salah satu makhluk hidup kematian tersebut justru menimbulkan akibat hukum tertentu, karena suatu kematian menurut hukum merupakan peristiwa hukum. ${ }^{2}$ Yaitu ketika seseorang meninggal dunia timbul persoalan terhadap harta yang ditinggalkan yang akan beralih kepemilikan ke orang yang ditinggalkan. ${ }^{3}$ Peralihan harta ini disebut dengan hukum waris.

Hukum kewarisan dalam Islam adalah hukum yang mengatur segala sesuatu yang berkenaan dengan peralihan hak dan atau kewajiban atas harta kekayaan seseorang setelah ia meninggal dunia kepada ahli warisnya. ${ }^{4}$ Hukum waris adalah ketentuan-ketentuan hukum yang mengatur tentang nasib kekayaan seseorang setelah meninggal. Waris berasal dari bahasa Arab "waratha" yang berarti pemindahan hak milik dari seseorang kepada orang lain setelah pemiliknya meninggal dunia. Harta warisannya disebut pusaka. ${ }^{5}$

Hukum waris Islam membawa perubahan penting dalam sistem pra-Islam. Untuk pertama kali wanita mewarisi -meskipun dalam hampir semua hal hanya berhak mendapat separo dari bagian ahli waris pria yang sama kedudukannya-. ${ }^{6}$

Hukum kewarisan dalam Islam berdasarkan pada prinsip hukum Islam dan memiliki asas-asas yang sesuai dengan prinsip-prinsip tersebut.

1 Suparman Usman, Ikhtisar Hukum Waris, (Serang: Darul Ulum Press, 1993), h. 49. 112.

${ }^{2}$ R. Abdul Djamali, Hukum Islam, (Bandung: Mandar Maju, 2002), h.

3 Suparman Usman, Ikhtisar Hukum Waris, h. 50.

4 Juhaya S. Praja, Filsafat Hukum Islam, (Bandung: LPPM UNISBA, 2002), h. 107.

${ }^{5}$ R. Abdul Djamali, Hukum Islam, h. 112.

6 John L. Esposito (et.al), Ensiklopedia Oxford, Jilid. VI (Bandung: Mizan, 2001), h. 156. 


\section{B. Hukum Waris dalam Islam}

Hukum kewarisan dalam Islam disebut hukum fara'id yang masuk dalam pembahasan ahwal shakhsiyyah, ${ }^{7}$ Fara’id adalah jamak dari farìdah yang secara harfiah berarti bagian. Kata farịtah atau fara'id ini erat pula hubungannya dengan makna fardlu yang berarti kewajiban yang harus dilaksanakan. Dengan demikian hukum fara'idl berarti hukum tentang pembagian harta warisan yang wajib ditaati pelaksanaannya oleh kaum muslimin. ${ }^{8}$

Pembahasan fara'id termasuk dalam pembahasan ahwal shakhșiyyah. Faraidh adalah aturan-aturan pembagian harta pusaka yang ditinggalkan seseorang karena meninggal dunia. ${ }^{9}$ Harta peninggalan tersebut harus dibagi-bagi sesuai dengan ketentuan yang telah ditetapkan dalam nash, setelah sebelumnya diselesaikan biaya pengurusan dan penguburannya, utang-utangnya, dan telah diselesaikan pula semua wasiatnya. Kemudian harta waris itu bisa didistribusikan kepada mereka yang berhak menerimanya setelah yang mewariskan hartanya itu betulbetul meninggal dunia, dan para pewarisnya betul-betul hidup, baik secara hakiki maupun syar'i, seperti janin yang masih ada dalam kandungan ibunya, atau orang yang menghilang sebelum secara pasti diketahui bahwa ia meninggal dunia. Dan terakhir, pewarisnya itu tidak melakukan tindakan-tindakan yang dapat menghalangi pendistribusian harta waris kepadanya. ${ }^{10}$

Perbuatan-perbuatan yang dapat menghalangi pendistribusian harta waris adalah pembunuhan yang dilakukan pewaris terhadap orang yang meninggalkan harta warisnya, atau beralih agama, karena Islam tidak

7 Dede Rosyada, Hukum Islam dan Pranata Sosial, (Jakarta: RajaGrafindo Persada, 1999), h. 82.

8 Juhaya S. Praja, Filsafat Hukum Islam, h. 107.

${ }_{9}^{9}$ Dede Rosyada, Hukum Islam dan Pranata Sosial, h. 82.

10 Ibid. 
membenarkan pendistribusian harta waris kepada orangorang non-muslim.

Mereka yang berhak mendapat harta waris adalah keluarga yang berada dalam garis nasab yang hakiki, yaitu anak bail laki-laki maupun perempuan, cucu baik laki-laki maupun perempuan dalam garis ke bawah. Ayah serta ibu, kakek dan nenek dalam garis ke atas.Saudara dan anak saudara, paman serta anak paman dalam garis ke samping. Inilah secara umum rangkaian ahli waris yang disebabkan nasab secara hakiki. DI samping itu, adapula ahli waris yang muncul karena ikatan perkawinan, yaitu suami istri.

Selain itu, ada pula jenis pendistribusian harta yang ditetapkan sebelum pemberi itu meninggal, tapi baru boleh direalisasikan setelah pemberi itu meninggal, tapi baru boleh direaisasikan setelah ia meninggal. Pemberian serupa disebut dengan wașiyyah (wasiat).

Wasiat itu disyariatkan dalam Islam. Namun hukumnya sagat dipengaruhi oleh keadaan, sehingga Sayyid Sābiq menyatakan bahwa wasiat itu adakalanya wajib, sunnah, haram, makruh dan mubah. ${ }^{11}$

Wasiat wajib adalah wasiat yang harus dilakukan seseorang menjelang kematiannya terhadap cucunya sendiri, baik dari anak laki-laki maupun perempuan yang telah mati sebelum ia meninggal dunia, yang jika ornag tuanya itu masih ada, niscaya dia akan memperoleh bagian dari harta waris melalui ayah atau ibunya. Sementara tanpa orang tuanya mereka terhijab oaleh paman dan tantenya sendiri.

Sedang wasiat sunnah adalah wasiat bagi kaum kerabat yang fakir atau orang-orang yang shaleh yang memerlukan harta. Akan tetapi wasiat ini haram dilakukan jika akan menimbulkan kesuliatan bagi ahli waris. Dan hukumnya menjadi makruh jika harta yang ditinggalkannya itu sedikit, sementara ahli warisnya pun masih

11 Ibid., h. 82-83.

Al-Qānūn, Vol. 20, No. 1, Juni 2017 
memerlukan harta itu. Hukum wasiat menjadi mubah jika pemilik harta itu kaya, sementara ahli warisnya pun tidak terlalu memerlukan harta yang akan diwasiatkannya itu.

Kemudian wasiat itu bisa dilakukan untuk bermacam-macam harta kekayaan yang secara hukum boleh dimiliki, serta ada manfaatnya, dan diwasiatkan kepada orang-orang yang bukan ahli waris, maksimal 1/3 harta peninggalannya, sebagaimana ditegaskan Rasulullah saw dalam haditsnya yang berbunyi:

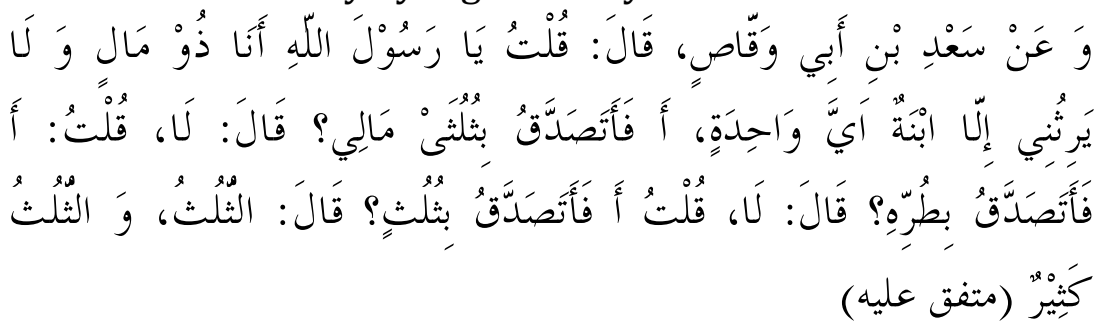

"Dari Sa'ad ibn Abi Waqqash, dia bertanya kepada Rasulullah: "Wahai Rasulullah saya punya harta dan hanya akan diwarisi oleh seorang anak perempuan, bolehkah saya mengeluarkan shadaqah 2/3 nya. Beliau menjawab tidak, atau separuhnya?, beliau menjawab juga tidak, atau sepertiganya?, beliau menjawab sepertiga itu cukup banyak". (H.R. Bukhari-Muslim).

Menurut Ismail, bahwa hukum waris dalam Islam berkenaan dengan hal-hal:

1. Yang berhak mewarisi dalam syariat Islam:

a. Keturunan garis ke atas dari orang yang meninggal; ayah, ibu, nenek.

b. Keturunan garis ke bawah dari orang yang meninggal; anak, cucu, dan seterusnya.

c. Keturunan garis ke samping; saudara, paman, bibi.

d. Keluarga karena perkawinan; istri atau suami.

2. Ajaran Islam menghilangkan perbedaan sifat pria dan wanita; pada dasarnya mereka mempunyai hak untuk 
mendapatkan waris walaupun ada perbedaan dari segi jumlah bagian yang diterima.

3. Ayah dan ibu yang masih hidup dan anak-anak pria atau wanita yang masih hidup tidak gugur hak warisnya oleh keadaan apapun walaupun ada perbedaan jumlah yang diterima karena perbedaan susunan, jumlahdan jenis kelamin dari orang tua dan anak, seperti ayah saja; ibu saja; anak laki-laki saja, atau anak laki-laki bersama anak perempuan atau anak perempuan saja dan seterusnya.

4. Saudara laki-laki atau perempuan gugur hak warisnya apabila ada ibu bapak dari yang emninggal demikian juga apabila ada anak.

5. Apabila terjadi bersama-sama mewarisi pria dan wanita dalam derajat yang sama seperti orang tua atau anak, maka bagian laki-laki dua kali bagian perempuan.

6. Berdasarkan prinsip-prinsip tersebut di atas harta warisan yang akan dibagi oleh ahli waris adalah harta peninggalan setelah diambil untuk pembayaran utangutang dan atau menunaikan wasiat si mati.

Wasiat menurut sebagian ulama tidak boleh diberikan kepada orang yang tidak membutuhkan harta itu demikian juga wasiat tidak boleh diberikan apabila sangat diperlukan untuk ahli waris. Rasulullah telah membatasi jumlah harta yang boleh diwasiatkan tidak boleh melebihi sepertiga harta yang ditinggalkan.

Rasulullah bersabda:

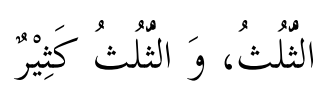

"Sepertiga dan sepertiga itu banyak" berfirman:

Dalam hal utang dan wasiat yang madrurat Allah

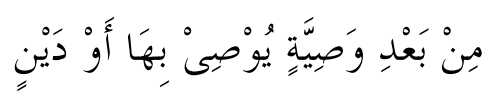

"Sesudah dipenuhi wasiat yang dibuat olehnya atau atau sesudah dibayar hutangnya dengan tidak memberi mudharat (kepada ahli waris)." (Qs. al-Nisā' (4): 12) 
Menurut ahli tafsir memberi madharat bagi ahli waris itu ialah tindakan-tindakan seperti:

1. Mewasiatkan lebih dari sepertiga harta peninggalan

2. Berwasiat denga nmaksud mengurangi harta warisan, sekalipun kurang dari sepertiga, bila ada niat mengurangi hak waris tidak diperkenankan. ${ }^{12}$

Hukum waris adalah ketentuan-ketentuan hukum yang mengatur tentang nasib kekayaan seseorang setelah meninggal. Waris berasal dari bahasa Arab "waratsa" yang berarti pemindahan hak milik dari seseorang kepada orang lain setelah pemiliknya meninggal dunia. Harta warisannya disebut pusaka. ${ }^{13} \mathrm{Hal}$ ini menunjukkan adanya unsur-unsur subyek hukum dan obyek hukum dalam pewarisan sebagai akibat terjadinya kematian. ${ }^{14}$

Subyek hukum dalam pewarisan adalah:

1. Pewaris, adalah orang yang meninggal dunia dan meninggalkan harta kekayaan.

2. Ahli waris, adalah orang yang menerima bagian dari harta warisan seorang pewaris. Ada empat hal yang menyebabkan seseorang menerima harta warisan:

a. Hubungan darah (nasab)

b. Perkawinan yang sah menurut agama Islam

c. Pembebasan hamba sahaya

d. Beragama Islam

Bagi ahli waris yang berhak menerima bagian harta warisan kedudukannya tidak mutlak menerima bagiannya. Ia dapat kehilangan hak waris kalau haltertentu dapat menghilangkannya. Dan hal tersebut adalah:

1. Murtad, yaitu keluar dari agama Islam

2. Bukan pemeluk agama Islam

3. Pembunuh

4. Budak belian

12 Ismail Muhammad Syah, Filsafat Hukum Islam, (Jakarta: Bumi Aksara, 1992), h. 229-230.

13 R. Abdul Djamali, Hukum Islam, h. 112.

14 Ibid., h. 113-116.

Al-Qānūn, Vol. 20, No. 1, Juni 2017 


\section{Ahli Waris}

Yang termasuk ahli waris adalah:

1. Kelompok pria, terdiri atas:

a. Anak laki-laki dari yang meninggal dunia

b. Cucu laki-laki dari anak laki-laki dan terus dalam garis lurus ke bawah

c. Bapak dari yang meninggal dunia

d. Kakek dari pihak bapak dan terus dalam garis lurus ke atas

e. Saudara laki-laki seibu sebapak

f. Saudara laki-laki seibu

g. Saudara lakki-laki sebapak

h. Keponakan laki-laki dari saudara laki-laki seibu sebapak

i. Keponakan laki-laki dari saudara laki-laki sebapak

j. Paman dari pihak bapak yang seibu sebapak

k. Paman dari pihak bapak yang sebapak

l. Anak laki-laki dari saudara laki-laki bapak yang seibu sebapak

m. Anak laki-laki dari saudara laki-laki bapak yang sebapak

n. Suami

o. Orang laki-laki yang membebaskan jenazah

2. Kelompok wanita, terdiri atas:

a. Anak perempuan

b. Cucu perempuan dari anak laki-laki dan terus dalam garis lurus ke bawah asal ikatan dari laki-laki

c. Ibu

d. Nenek dari pihak bapak

e. Nenek dari pihak ibu dan terus dalam garis lurus ke atas asal tidak diselang laki-laki

f. Saudara perempuan seibu sebapak

g. Saudara perempuan sebapak

h. Istri

i. Orang perempuan yang membebaskan jenazah 


\section{Obyek Hukum dalam Pewarisan}

Obyek hukum dalam pewarisan adalah harta waris, atau pusaka. Dalam pembagiannya terdapat hak-hak yang didahulukan sebelum harta peninggalan itu dibagikan kepada ahli warisnya. Yaitu:

1. Hak yang bersangkutan dengan harta peninggalan seperti zakat dan lainnya

2. Biaya untuk keperluan jenazah

3. Hutang

4. Wasiat

Dari uraian pengertian hukum di atas, maka dapat ditarik suatu makna bahwa asas kewarisan menurut hukum Islam yaitu bilateral dengan:

1. Mendudukkan anak bersama-sama orang tua pewaris serentak sebagai ahli waris

2. Dalam hal pewaris tidak mempunyai keturunan, maka saudara-saudaranya bersama-sama orang tua menjadi ahli waris

3. Suami istri saling mewaris

4. Mengenal faraidl yaitu bagian tertentu bagi ahli waris tertentu

Asas bilateral secara prinsipil menunjukkan bahwa harta warisan harus dibagi kepada ahli waris yang berhak baik pria meupun waita dengan adil. Dan adil yang dimaksud adalah sesuai dengan kodratnya bahwa harta warisan dibagikan untuk setiap anggota keluarga yang berhak menerima dan dalam kepentingan keseluruhan supaya terjamin kelangsungan hidup yang sejahtera.

Mengenai pembagian harta warisan sebagai suatu amanat menunjukkan adanya kepercayaan yang diberikan Allah, sebab kekayaan yang dimiliki seseorang berasal dari Allah. Dan dalam penggunaannya wajib sesuai dengan ajaran dan hukum-hukum Allah.

Mengenai pembagian harta warisan sebagai suatu amanat menunjukkan adanya kepercayaan yang diberikan 
Allah untuk digunakan dengan baik supaya para ahli waris yang berhak menerima ikut menikmatinya. Karena itu pewarisan dalam hukum Islam tidak saja hanya untuk kepentingan pria dan wanita yang berhak menerima melainkan juga bagi kepentingan setiap orang yang berhak menerimanya. Bahkan kalau ada wasiat yang mengenyampingkan ahli waris, maka waisat itu berlaku hanya sepertiga bagian dan dua pertiga lainnya menjadi hak dari para ahli waris. Dengan demikian dapat dikatakan bahwa dasar pemikiran hokum waris ini selain berasaskan bilateral juga bertujuan untuk ekpentingan orang lain di luar ahli waris kalau ada wasiat. 15

Pembagian harta warisan

\section{E. Penggolongan dari}

Terdapat penggolongan atau pengelompokan dalam pembagian waris dalam fiqih Islam. Golongan atau kelompok ahli waris tersebut adalah sebagai berikut:

1. Dhawu al-furūd, ialah ahli waris yang memperoleh bagian harta warisan tertentu dan dalam keadaan tertentu.

Bagian tertentu dimaksudkan dengan porsi yang diterima sesuai dengan ketentuan al-Qur'an. Dalam keadaan tertentu yaitu ahli waris masih hidup ketika pewaris meninggal dunia. Dzawil furudh terdiri dari:
a. Suami
b. Istri
c. Anak perempuan
d. Cucu perempuan dari anak laki-laki dan terus dalam garis lurus ke bawah asal ikatan dari laki-laki
e. Bapak
f. Kakek dari pihak bapak dan terus dalam garis lurus ke atas
g. Ibu

15 Ibid., h. 120. 
h. Nenek dari puhak bapak]

i. Nenek dari pihak ibu dan terus dalam garis lurus ke atas asal tidak diselang laki-laki

j. Saudara perempuan seibu sebapak

k. Saudara perempuan sebapak

l. Saudara perempuan seibu

m. Saudara laki-laki seibu

2. 'Așabah, yaitu ahli waris yang berhak menghabiskan harta warisan setelah dikurangi hak-hak yang didahulukan kalau tidak ada dhawu al-furud kalau masih ada sisa atau tidak memperoleh bagian dari dhawu al-furüd yangtidak ada sisa.

Asabah terdiri atas:

a. 'Așabah bi nafsih, ialah laki-laki yang mewaris Karena kedudukannnya yangmempunyai hak sendiri, seperti anak laki-laki, cucu laki-laki dari anak laki-laki.

b. 'Așabah bi ghairih, ialah perempuan yang mewaris karena didampingi oleh asabah binagsihi yang sederajat, seperti:Anak perempuan yang didampingi anak laki-laki.

c. 'Așabah ma' al-ghair, ialah saudara perempuan pewaris yang mewaris (menjadi asabah) bersamasama keturunan perempuan pewaris dalam garis perempua, seperti: Saudara perempuan pewaris bersama sama anak perempuan pewaris.

3. Dhawu al-arhām, yaitu ahli waris dalam hubungan nasab (keluarga sedraah) yang tidak termasuk dhawu al-furud atau asabah. Keluarga sedarah yang merupakan dhawu al-arham itu diantaranya adalah:

a. Saudara perempuan sebapak

b. Saudara perempuan dari kakek ${ }^{16}$

16 Ibid., h. 121-124. 
Sedangkan rukun pewarisan ada tiga, yaitu: (1) pewaris, (2) ahli waris, dan (3) harta yang diwariskan.

Selain itu, untuk dapat terlaksananya pewarisan harus dipenuhinya beberapa syarat. Sedangkan syarat pewarisan adalah sebagai berikut:

1. Meninggalnya pemilik harta.

2. Ahli waris yang hidup.

3. Adanya harta waris yang ditinggalkan.

\section{F. Asas-Asas Pewarisan dalam Islam}

Hukum kewarisan dalam Islam bersumberkan pada Al-Qur'an, khususnya dalam QS. al-Nisā' ayat 11, 12, 176 dan Sunnah Rasul Allah. Sebagai hukum yang bersumberkan wahyu, hukum kewarisan Islam mempunyai asas-asas yang didasarkan atas atau sesuai dengan prinsipprinsip umum hukum Islam. Asas-asas tersebut adalah sebagai berikut:

\section{Asas Ijbāry}

Asas ijbary secara harfiah berarti memaksa. Asas ini merupakan kelanjutan dari prinsip tauhid yang mengandung arti bahwa peralihan harta dari seorang yang meninggal dunia kepada ahli warisnya berlaku dengan sendirinya menurut ketetapan Allah tanpa digantungkan kepada kehendak si pewaris atau ahli warisnya.

Asas ijbarry hukum kewarisan Islam dapat dilihat dari tiga segi, yaitu:

Pertama, peralihan harta yang pasti terjadi setelah orang meninggal dunia sesuai dengan firman Allah dalam QS. al-Nisā' (4): 7, yang artinya: “... laki-laki ada bagian dari harta peninggalan kedua orang tuanya dan kerabatnya, dan bagi wanita ada bagian dari apa yang ditinggalkan oleh kedua orang tua dan kerabatnya, baik sedikit maupun banyak, sebagai suatu bagian (warisan) yang telah ditetapkan." 
Dalam ayat tersebut di atas disebutkan bahwa bagi laki-laki dan bagi perempuan ada nașib atau bagian, yakni warisan, dari harta peninggalan ibu bapak dan keluarga dekatnya. Kata nașib dalam ayat ini mengandung pengertian bahwa di dalam harta yang ditinggalkan oleh pewaris itu terdapat bagian atau hak ahli waris. Oleh karena itu, si pewaris tidak perlu menjanjikan sesuatu yang akan diberikan kepada ahli warisnya sebelum ia meninggal dunia. Demikian juga sebaliknya, si ahli waris tidak perlu meminta-minta haknya kepada calon pewarisnya. ${ }^{17}$

Kedua, jumlah harta bagi masing-masing ahli waris sudah ditentukan. Hal ini tercermin dalam kata mafru'dan yang makna generiknya adalah ditentukan atau diperhitungkan. Apa yang sudah ditentukan atau diperhitungkan oleh Allah wajib dilaksanakan oleh hambaNya. Sifat wajib dalam kata mafru'dan itu memaksa manusia muslim untuk melaksanakan ketentuan yang sudah ditetapkan Allah.

Ketiga, Kepastian mereka yang berhak menerima harta peninggalan, yakni mereka yang mempunyai hubungan darah dan ikatan perkawinan dengan pewaris. Mereka yang berhak menjadi ahli waris itu dirinci dalam pengelompokkan ahli waris dalam surat al-Nisa' ayat 11 , 12, dan 176. Karena rinciannya itu sudah pasti, maka tidak ada satu kekuasaan manusia pun yang dapat merubahnya. Oleh karena itu, seringkali ayat-ayat tentang kewarisan tersebut di atas mengandung pengertian compulsory yaitu hukum yang bersifat wajib dilaksanakannya sesuai dengan ketetapan Allah. ${ }^{18}$

\section{Asas Waratha}

Asas waratsa diambil dari kata waratha yang banyak dijumpai dalam Al-Qur'an. Waratsa dalam Al-Qur'an mengandung pengertian makna peralihan harta setelah

${ }^{17}$ Juhaya S. Praja, Filsafat Hukum Islam, h. 107.

18 Ibid., h. 107. 
kematian. Asas waratsa ini menyatakan bahwa kewarisan itu hanya ada kalau ada yang meninggal dunia. Ini berarti bahwa kewarisan dalam hukurn Islam itu semata-mata sebagai akibat dari kematian seseorang. ${ }^{19}$

Peralihan harta seseorang kepada orang lain yang merupakan kewarisan itu hanya terjadi bila orang yang mempunyai harta meninggal dunia. Harta seseorang tidak dapat beralih kepada orang lain dengan sebutan sebagai harta warisan selama orang yang mempunyai harta itu masih hidup.

\section{Asas Thuluthay al-Mal}

Sebagai imbangan kewarisan testamen dalam sistem hukum perdata Barat, hukum Islam mengenal wasiat dengan berdasarkan asas thuluthay al-mal. Asas thuluthay al-mal menyatakan bahwa wasiat tidak boleh melebihi sepertiga dari jumlah harta peninggalan. Pelaksanaan asas thuluthay al-mal ini harus berdasarkan kaidah: $l \vec{a}^{\prime}$ wașiyyah li wärith illa an yujiza al-warathah (Tidak ada hak menerima wasiat, kecuali para ahli waris membolehkannya). Harta yang diperoleh melalui wasiat itu tidak dapat disebut sebagai harta. waris. ${ }^{20}$

\section{Asas Bilateral}

Asas bilateral di sini berarti bahwa seseorang menerima hak atau bagian warisan dari kedua belah pihak: dari kerabat keturunan laki-laki dan dari kerabat perempuan. ${ }^{21}$

Asas ini dapat dijumpai dasar hukumnya dalam berbagai ayat al-Qur'an, yang rinciannya sebagai berikut;

a. QS. Al-Nisā' (4): 7

Ayat ini menegaskan bahwa seorang laki-laki berhak mendapat warisan dari ayahnya dan juga dari ibunya.

\footnotetext{
19 Ibid., h. 108.

20 Ibid., h. 109.

${ }^{21}$ Ibid.
} 
Demikian juga perempuan, ia berhak mendapat warisan dari kedua orang tuanya.

b. QS. Al-Nisā' (4): 11

Ayat ini menegaskan hal-hal berikut:

1) Anak perempuan berhak menerima warisan dari orang tuanya sebagaimana halnya dengan anak lakilaki dengan perbandingan bagian seorang anak lakilaki sebanyak bagian dua orang anak perempuan;

2) lbu berhak mendapat warisan dari anaknya, baik laki-laki maupun perempuan, sebesar seperenam. Demikian juga ayah berhak menerima warisan dari anaknya, baik laki-laki maupun perempuan, sebesar seperenam, bila pewaris meninggalkan anak.

c. QS. Al-Nisā' (4): 12

Ayat ini menjelaskan bahwa (1) bila seorang laki-laki mati punah, maka saudaranya yang laki-lakilah yang berhak atas harta peninggalannya, juga saudaranya yang perempuan berhak mendapat harta warisannya itu; (2) bila pewaris yang mati punah itu seorang perempuan, maka saudaranya, baik laki-laki maupun pemmpuan, berhak menerima harta warisannya.

d. Ayat 176 al-Nisa'

Ayat ini menyatakan bahwa (1) seorang laki-laki yang tidak mempunyai keturunan, sedangkan ia mempunyai saudara perempuan, maka saudaranya yang perempuan itulah yang berhak menerima warisannya; (2) seorang perempuan yang tidak mempunyai keturunan, sedangkan ia mempunyai saudara laki-laki, maka saudaranya yang laki-laki itulah yang berhak menerima harta warisannya.

Ahli waris keluarga dekat (al-aqrabūn) yang tidak tersebut secara nyata di dalam Al-Qur'an dapat diketahui dari penjelasan yang diberikan oleh Rasul Allah. Dapat juga diketahui dari perluasan pengertian ahli waris yang disebutkan dalam Al-Qur'an. Perluasan pengertian tersebut dapat diambil dari kata-kata $a b b$; umm, walad, ibn, ikhawah, 
dan aqrabūn, baik dalam Al-Qur'an rnaupun Sunnah. Kata $a b b$ dalam bahasa Arab berarti Kakek secara umum; kata ummun atau ummi (material = material grandmother) berarti nenek dari pihak ibu. Di samping itu terdapat juga penjelasan dari Rasul Allah tentang kewarisan kakek dan kewarisan nenek. Dari perluasan pengertian itu dapat pula diketahui garis kerabat ke atas melalui pihak laki-laki dan melalui pihak perempuan. ${ }^{22}$

Kata walad dalam ayat-ayat waris memberi isyarat adanya garis kerabat ke bawah sebagai ahli waris, walaupun tidak secara tegas disebutkan dalam Al-Qur'an. Kata walad dapat diperluas artinya, baik dalam pengertian anak laki-laki maupun anak perempuan dan keturunannya. Akan tetapi, perluasan makna ini di kalangan masyarakat yang berfaham Sunnisme terbatas pada pengertian anak laki-laki dan keturunannya, seperti halnya yang terdapat dalam masyarakat patrilinial. Sementara di kalangan masyarakat yang menganut madzhab Syi'ah, makna walad diperluas sehingga mencakup anak-laki-laki dan anak perempuan, serta cucu melalui anak laki-laki dan anak perempuan. ${ }^{23}$

Pengertian aqrabūn pun dapat diperluas pengertiannya, yakni dalam pengertian kekerabatan bilateral dan kekerabatan melalui garis ke samping. Perluasan makna ini dapat diambil dari QS. al-Nisā' (4): 12 dan 176. Ayat 12 tersebut menetapkan kewarisan saudara laki-laki dan saudra perempuan dengan pembagian yang berbeda dengan hak atau bagian yang diperoleh saudara dalam ayat 176. Perbedaan itu menunjukkan adanya perbedaan dalam hal (orang) yang berhak menerima warisan. Oleh karena hak saudara, baik laki-laki maupun perempuan, dalam ayat 12 adalah seperenam atau sepertiga, sama dengan bagian ibu, maka dapat ditarik suatu kesimpulan bahwa yang dimaksud dengan saudara-

\footnotetext{
22 Ibid., h. 110.

23 Ibid., h. 111.
}

Al-Qānūn, Vol. 20, No. 1, Juni 2017 
saudara (ikhwah) dalam ayat 12 itu adalah suadara garis ibu, sedang saudara dalam ayat 176 adalah saudara garis ayah atau ayah dan ibu. Dengan demikian, dapatlah ditarik kesimpulan bahwa pada garis kerabat ke samping pun berlaku kewarisan dua arah, melalui arah ayah dan arah ibu.

\section{Asas Keadilan atau Keseimbangan}

Dalam al-Qur'an banyak dijumpai kata al-'adl yang sama pengertiannya dengan kata al-mízan dan al-qisț. Kata al-'adl dapat diterjemahkan ke dalam bahasa Indonesia dengan kata adil atau keadilan. Kata al-mizān berarti timbangan, yakni keseimbangan antara batu timbangan dengan benda yang ditimbang. Oleh karena itu, keadilan menjadi prinsip umum hukum Islam yang penerapannya dalam hukum kewarisan melahirkan asas keadilan atau keseimbangan.

Asas keadilan atau keseimbangan di sini mengandung arti bahwa harus senantiasa terdapat keseimbangan antara hak dan kewajiban; antara hak yang diperoleh seseorang dengan kewajiban yang harus ditunaikannya. Dalam hukum kewarisan Islam, harta peninggalan yang diterima oleh ahli waris dari pewaris pada hakikatnya merupakan kelanjutan tanggung jawab pewaris terhadap keluarganya. Oleh karena itu, bagian yang diterima oleh masing-masing ahli waris harus berimbang dengan perbedaan tanggungjawab masingmasing terhadap keluarganya. Seorang laki-laki menjadi penanggungjawab kehidupan keluarga, yakni mencukupi keperluan hidup anak dan isterinya (QS. al-Baqarah (2): 233) menurut kemampuannya (QS. al-Ṭalaq (65): 7). Tanggungjawab itu merupakan kewajiban agama yang harus dilaksanakannya, terlepas dari persoalan apakah isterinya mampu atau tidak; anaknya memerlukan bantuan atau tidak. Terhadap kerabat lain, tanggungjawab seorang laki-laki juga ada (QS. al-Baqarah (2): 177). Berbeda 
dengan laki-laki., tanggungjawab perempuan tidak seberat tanggungjawab laki-laki terhadap keluarganya. Perempuan justeru harus menerima infaq, maskan (tempat tinggal), dan nafkah lainnya dari suaminya. Dengan demikian, sesungguhnya manfaat yang dirasakan oleh laki-laki dan perempuan dari harta peninggalan yang mereka peroleh adalah sama. Dapatlah difahami rasa keadilan hukum Islam dalam kewarisan di mana bagian anak laki-laki dua kali bagian anak perempuan itu didasarkan atas perbedaan tanggung jawab yang hakikatnya masing-masing samasama merasakan manfaat yang sama dari perbedaan pembagian tersebut. ${ }^{24}$

\section{Asas Individual}

Asas individual dalam hukum kewarisan Islam berarti bahwa harta warisan dapat dibagi-bagikan kepada ahli waris untuk dimiliki secara perorangan. Dalam melaksanakan asas ini seluruh harta warisan dinyatakan dalam nilai tertentu yang kemudian dibagikan kepada setiap ahli waris yang berhak menerimanya menurut kadar bagian masing-masing. Dalam hal ini, setiap ahli waris berhak atas bagian yang didapatnya tanpa terikat kepada ahli waris yang lain, karena bagian masing-masing telah ditentukan (mafrüdan). Dasar hukum asas ini pun merujuk kepada QS. al-Nisā' (4): 7, 12, dan 176. ${ }^{25}$

Bila pembagian harta warisan telah dilaksanakan sesuai dengan asas individual, maka setiap ahli waris berhak berbuat atau bertindak atas harta yang diperolehnya itu (mentasharrufkan hartanya) kalau ia telah mempunyai kernampuan untuk bertindak hukum atas hartanya itu (al-rushd), yakni apabila ia telah mempunyai ahliyyah al-ada dan ahliyyah al-wujub sekaligus. Bila ia belum memiliki kemampuan bertindak atas hartanya itu, maka diangkatlah wali yang bertanggungjawab mengurus

\footnotetext{
${ }^{24}$ Ibid.
}

25 Ibid.

Al-Qānūn, Vol. 20, No. 1, Juni 2017 
harta tersebut. Wali bertanggung jawab mengembalikan harta tersebut kapada orang yang ada di bawah perwaliannya manakala ia telah memiliki kernampuan bertindak secara hukum atas hartanya. Harta wali dengan harta orang yang ada di bawah perwaliannya tidak boleh bercampur karena bertentangan dengan asas individual tersebut di atas. ${ }^{26}$

\section{G. Asas-asas Kewarisan dalam Kompilasi Hukum Islam}

Instruksi Presiden Nomor 1 Tahun 1991 tentang penyebarluasan Kompilasi Hukum Islam, yang lebih populer dengan sebutan Kompilasi Hukurn Islam (KHI), menjelaskan bahwa asas-asas kewarisan yang dianut adalah sebagai berikut:

1. Asas ijbarry dapat dilihat dalam ketentuan umum mengenai perumusan pengertian kewarisan, pewaris, dan ahli waris. Asas ijbari mengenai peralihan harta waris disebut dalam pasal 187 (2). Tentang bagian masing-masing ahli waris disebutkan dalam Bab III, Pasal 176 sampai 182. Mengenai siapa ahli waris disebut dalam bab II, Pasal 174 (1) dan(2).

2. Asas waratsa dapat dilihat dalam Ketentuan Umum dan Pasal 171 yang menjelaskan istilah-istilah hukum kewarisan, pewaris, ahli waris dan harta peninggalan. Sementara asas wasia dijelaskan dalam Bab V.

3. Asas bilateral terdapat dalam pasal 174 ayat (1) yang menyebutkan kelompok ahli waris, yaiu golongan menuru hubungan darah yang terdiri dari golongan laki-laki (ayah, anak laki-laki, saudara laki-laki, paman dan kakek); dan, golongan perempuan (ibu, anak perempuan, saudara perempuan dan nenek). Sementara duda dan janda menjadi golongan ahli waris berdasarkan perkawinan. ${ }^{27}$

${ }^{26}$ Ibid., h. 112.

27 Ibid.

Al-Qānūn, Vol. 20, No. 1, Juni 2017 


\section{H. Penutup}

Dari berbagai pemaparan di atas maka dapat diambil kesimpulan sebagai berikut:

1. Hukum waris dalam Islam berkenaan dengan: (1) yang berhak mewarisi, (2) menghilangkan perbedaan sifat pria dan wanita, (3) ayah dan ibu selalu mendapatkan warisan, (4) saudara laki-laki atau perempuan gugur hak warisnya apabila ada ibu bapak, (5) jika terjadi bersama-sama mewarisi pria dan wanita dalam derajat yang sama maka bagian laki-laki dua kali bagian perempuan, dan (6) harta warisan baru dibagikan kepada ahli waris setelah dikurangi pembayaran utang dan/atau penunaian wasiat.

2. Dalam pembagiannya terdapat penggolongan atau pengelompokan, yaitu: (1) dhawu al-furūd, (2) 'așabah, dan (3) dhawu al-arhām

3. Terdapat enam asas dalam pewarisan Islam, yaitu: (1) asas ijbary, (2) asas waratha, (3) asas thuluthay al-mal, (4) asas bilateral, (5) asas keadilan atau keseimbangan, dan (6) asas individual

4. Sedangkan dalam pewarisan Islam di Indonesia terdapat tiga asas yang dianut, sebagaimana dalam Kompilasi Hukum Islam, yaitu: (1) asas ijbarry, (2) asas waratsa, dan (3) asas bilateral.

\section{Daftar Pustaka}

Dede Rosyada. Hukum Islam dan Pranata Sosial. Jakarta, RajaGrafindo Persada, 1999.

Ismail Muhammad Syah. Filsafat Hukum Islam. Jakarta, Bumi Aksara, 1992.

John L. Esposito (et.al). Ensiklopedia Oxford, Jilid. VI. Bandung, Mizan, 2001. 
Juhaya S. Praja. Filsafat Hukum Islam. Bandung, LPPM UNISBA, 2002.

R. Abdul Djamali. Hukum Islam. Bandung, Mandar Maju, 2002.

Suparman Usman. Ikhtisar Hukum Waris. Serang, Darul Ulum Press, 1993. 